\title{
Internalizing the Value of Patience in Telling Bedtime Stories Activity in Sundanese Societies
}

\author{
M Supriatna ${ }^{1}, \mathbf{R}$ Wismaliya ${ }^{2}$, \\ $\left\{{ }^{1}\right.$ ma2t.supri@upi.edu, ${ }^{2}$ risawismaliya@upi.edu $\}$ \\ ${ }^{1,2}$ Universitas Pendidikan Indonesia, Indonesia
}

\begin{abstract}
This article aims to obtain the comprehensive description of how far the patience value internalization in bedtime storytelling activities in Sundanese society that useful for future children's personality development. Qualitative research applied in this study. Data collecting techniques used in this study through observations and interviews. Observation was carried out by observation guide in several Sundanese people houses whose mothers did storytelling activities before sleeping with their children. Then the interview was conducted to the mother as a storyteller with an interview guide, and the child was also interviewed as cross check data. The results show that the patience value is internalized before doing storytelling activities and when it takes place.
\end{abstract}

Keywords: Telling Bedtime Stories Activity, Internalizing The Value of Patience

\section{INTRODUCTION}

Storytelling activity becomes a habit done by parents especially by a mother to her child [1]. In some regions and even across countries, bedtimes stories become a family routine [1] and Indonesian people, including the people who carry out these activities, especially Sundanese people. Some of the fairy tale titles that are told are diverse. it is ranging from local fairy tale that are only told in that area or nationally it is often told by the parents to their children. The language used is not only in Indonesian, but also in regional language or mother tongue.

Based on the explanation before, there are some series of educational processes in the family carried out by parents to their children. One thing that appears is the value internalization process. One of the value internalization in the storytelling activity before sleeping is patience value. This patience is considered as a value that will be passed on to the children from their parents. This patience value will be explored starting from before storytelling activities are carried out and when it takes place. Besides being a developing culture in Sundanese society, storytelling activities before sleeping can be a tool for internalizing the patience value carried out by parents to their children as a part of family education, including literary literacy education.

Storytelling activities before sleeping is the traditional form of storytellers, where a story is told to children at their bedtimes to prepare them to sleep. Bedtime stories have long been considered as "education that is mostly done by families in general" [2]. If Stockman describes the storytelling activities before sleeping as a family routine activity [3] views it from its form. Bedtime stories are a form of traditional solace, where the story is read to children at their 
bedtime to prepare them to sleep. Bedtime stories can be read from a book, or told verbally by the storyteller. The story usually has a short plot with happy ending. Therefore, storytelling activities before sleeping is an activity carried out by adults to children at the children's bedtime that has educational values on it.

Value internalization is an effort to present a value that originally existed in the external and it becomes internal property for a person or institution. Therefore, value internalization means the recognition of external values that are deemed necessary to belong to someone [4]. In other words, the value internalization is the process of entering a value or incorporating ideal attitudes that were previously considered to be outside, so that are incorporated into someone's thinking in the thoughts, skill, and attitudes of someone's views of life. Meanwhile, patience is holding back or steadfastly facing something difficult [5]. This definition can apply in everyday life that ordinary people say the word patience in life. Meanwhile, [6] expresses the understanding of patience as a sense of being able to bear. This is based on the fact that the person who is patient is able to bear every event that comes to him, both of pleasant and otherwise. So that patience can be interpreted as a feeling of being able to accept the conditions that apply to us both of difficult and happy situations. Therefore, the internalization of patience value in storytelling activities before sleeping is internalized by parents to their children.

\section{RESEARCH METHOD}

Qualitative research applied in this study. Data collecting techniques used in this study through observations and interviews. Observation was carried out by observation guide in several Sundanese people houses whose mothers did storytelling activities before sleeping with their children. Then the interview was conducted to the mother as a storyteller with an interview guide, and the child was also interviewed as cross check data.

The participants are Sundanese people in Ciamis, West Java. Precisely in the District of Cihaurbeuti.

\section{RESULT AND DISCUSSION}

\subsection{Form of Storytelling before Sleeping}

The form of storytelling before sleeping is in the form of stories that are delivered verbally by parents to their children. This fairy tale is pronounced in regional languages or mother tongue with distinctive expressions. Usually it is told in an instrumental movement tone and slowly is like lulling. There are a number of fairy tales interspersed by soft songs[3].

Interview with one of the Sundanese storytellers, Nike Sopiyah, she said that other forms of storytelling before sleeping such as storytelling only verbally, storytelling using hand tools as the character's incarnation in storytelling, and storytelling with storybook.

\subsection{The Process of Storytelling Activities before Sleeping}

This activity is carried out at night before the child sleeps. Usually done while lying on a bed with the position of children and parents close together so that the expression of social bonds is intertwined [7]. Storytelling before sleeping requires physical closeness between parents and their children. Not only to a slow voice to lull, but also caress from parents becomes an inseparable part. Besides, not only spoken language but also hand movements become a tool for expressing stories. 
Storytelling before sleeping, can be a gift or even a punishment tool for children [7]. In this case, storytelling activities is an interesting thing and is positioned as a "gift" after a full day of children undergoing their activities. Storytelling activities before sleeping is awaited by the child. Therefore, when children make mistakes or have punishment from parents, storytelling before sleeping can be used as a tool not to be given to children. This position adds to the sanctity of storytelling activities before sleeping.

Some benefits which are activities of storytelling before sleeping have a side of sustainability benefits obtained from a representative learning and learning that fosters understanding, values, attitudes and intra-cultural skills [8]. Besides that, storytelling before sleeping provides vocabulary enrichment for children in speaking and reading [9]. This is confirmed by the opinion of Hörschelmann [10] who said that "Sleep tends to be considered as a period of calm and tranquility when the body and mind relax. This assumption is partly wrong because sleep is actually an active process. Thus, there are intentions and values contained in storytelling activities before sleeping because the true mind of the subconscious human being in this case is still functioning. In line with that, the benefits of storytelling before going to bed can reduce the risk of sleep that is not healthy for children or the risk of insomnia in children [11] - [12] [13]

\subsection{The Process of Internalizing Patient Values}

Before sleeping, the mothers prepare to do storytelling activities before sleeping. However, the child is told to be patient first, because the child must do some pre-fairytale activities that the child considers to be their gift to listen. Among them, the child must do the worship first, such as prayer, then brush his teeth, wash his feet and hands, change his nightgown and prepare a bed. Here children are trained in patience to listen to bedtime stories.

When the fairy tales take place, children are trained in patience to listen to the story completely without pausing the story in the middle. Children also keep questions that if they want to ask. They can ask only at the end when the story. The child does not complain about the story and patiently listens to how the storyline flows. Some of the benefits among storytelling activities before going to sleep have benefits as a culture is teaching and learning that foster intra-cultural understanding, values, attitudes and skills. [14][15][16].

\section{CONCLUSIONS}

Storytelling activities before sleeping is an educational activity carried out by parents to their children just before the child is at bedtime. With various stories told by using mother tongue and as a process of internalizing the value of patience. This patience value is internalized when starting to prepare storytelling, and when storytelling takes place.

\section{ACKNOWLEDGEMENTS}

The researchers thanked to all the parties concerned. Mothers and their children in District Cihaurbeuri, Ciamis West Java.

\section{REFERENCES}

[1] S. Nichols, "Unsettling the Bedtime Story: Parents' Reports of Home Literacy Practices," Contemp. Issues Early Child., vol. 1, no. 3, pp. 315-328, 2005. 
[2] Vocational guidance for girls _ Dickson, Marguerite _ Free Download, Borrow, and Streaming _ Internet Archive. .

[3] H. Setiawan, Mendongeng Sebelum Tidur. Malang: ASRA PRES, 2016.

[4] K. A. \& N. Hakam, Metode Internalisasi Nilai. Bandung: Maulana Media Grafika, 2016.

[5] M. Q. dkk Shihab, Ensiklopedia Al-Quran: Kajian Kosakata. Jakarta: Lentera Hati. Pusat Studi Al-Quran dan Yayasan Paguyuban Ikhlas., 2007.

[6] A. . Munawir, Al-Munawir: Kamus Arab Indonesia. Surabaya: Pustaka Progresif, 1997.

[7] S. and W. J. Albert, The Temporal Transition from Being Together to Being Alone: The Significance and Structure of Children's Bedtime Stories. New York: Plenum Press, 1977.

[8] D. Supriatna M, Pheeney, C, "Harnessing Social Media to Ethno-Pedagogy," in Proceeding of Asia Pacific HCI and UX Design Symposium, pp. 5-9.

[9] K. Love and J. Hamston, "Committed and Reluctant Male Teenage Readers.pdf," pp. 335-400, 2004.

[10] H. et Al, Contested Bodies of Childhood and Youth. New York: Palgrave Macmillan, 2010.

[11] J. Porter, "Guided Fantasy as a Treatment for Childhood Insomnia," Aust. New Zeal. J. Psychiatr, vol. 9, p. 169, 1975.

[12] S. J. Brown, K. E. Rhee, and S. Gahagan, "Reading at Bedtime Associated with Longer Nighttime Sleep in Latino Preschoolers," Clin. Pediatr. (Phila)., vol. 55, no. 6, pp. 525$531,2015$.

[13] C. E. Izard, The Personal Experience of Time. 2013.

[14] D. Supriatna M, Pheeney, C, "Ethno-Pedagogy, Harnessing Social Media to," Proceeding Asia Pacific HCI UX Des. Symp., p. Pg.5-9., 2015.

[15] R. P. Costa, "Choreographies of Emotion: Sociological Stories behind Bedtime, Fairy Tales and Children's Books," Glob. Stud. Child., vol. 2, no. 2, pp. 117-128, 2012.

[16] K. Saddhono, "Language of Coastal Communities in the Northern Coast of Central Java: Sociolinguistic Studies in Cultural Integration Maritime-Agrarian Perspective." Adv. Sci. Let. vol. 23 no. 10 pp 10054-10056, 2017 